\title{
PENDIDIKAN SEBAGAI INSTITUSI SOSIAL
}

\author{
Sulaiman Saat \\ Fakultas Tarbiyah dan Keguruan UIN Alauddin Makassar \\ Kampus II: Jalan Sultan Alauddin Nomor 36 Samata-Gowa \\ Email: sulaimansaat@yahoo.co.id
}

\begin{abstract}
Abstrak:
Pendidikan dan masyarakat tidak dapat dipisahkan. Pendidikan berlangsung dalam masyarakat, dan eksistensi dan kualitas hidup masyarakat ditentukan oleh tingkat pendidikan yang dialaminya. Sebagai institusi sosial, pendidikan tumbuh dan berkembang dalam masyarakat tanpa mengenal tingkat kebudayaan, apakah masyarakat bersahaja atau masyarakat modern. Seiring dengan perkembangan masyarakat, mucul pula kebutuhan-kebutuhan terhadap lembaga-lembaga/institusi sosial merupakan kumpulan norma yang berkisar pada suatu kebutuhan pokok dalam kehidupan masyarakat, termasuk pendidikan. Dengan demikian, lahirlah lembaga pendidikan sebagai institusi sosial, mulai taman kanak-kanak, SD, SLTP, SLTA, dan pendidikan tinggi.
\end{abstract}

\begin{abstract}
:
Education and society cannot be separated; education takes place in society while the existence and the quality of society's life were determined by the level of education experienced. As a social institution, education grows and develops in society without knowing the level of culture, whether in traditional or modern society. Along with the development of society, raise also a demand to agencies and social institutions, a set of norms that revolve around a basic need in people's lives, including education. Thus, educational institutions are born as social institutions, from kindergarten, elementary, junior high, high school, and higher education.
\end{abstract}

\section{Kata kunci:}

Pendidikan, Institusi sosial, Masyarakat.

SETIAP orang merupakan bagian dari suatu sistem sosial. Tidak seorangpun merupakan sebuah pulau yang terpisah" kata John Donne, seorang penyair dan pendeta, abad ke tujuh belas. ${ }^{1}$ Gunawan dalam Muhyi Batubara mengatakan, manusia sebagai pribadi tidak dapat hidup dan menghayati eksistensinya secara wajar kecuali hidup bersama dengan sesamanya. Mereka satu sama lain saling membutuhkan, sebab pada hakekatnya manusia adalah makhluk sosial. ${ }^{2}$

Masyarakat terbangun dari individu-individu yang saling berinteraksi. Hubungan interaksi antara individu melahirkan berbagai aktivitas untuk memenuhi kebutuhan masyarakat, salah satu di antaranya adalah kebutuhan akan pendidikan. Pendidikan tidak dapat dipisahkan dari sistem sosial, karena ia merupakan produk yang lahir dan tumbuh dalam masyarakat pembangunnya. Pendidikan merupakan gambaran kemajuan dari suatu masyarakat. Pendidikan yang maju, hanya hidup dan dimiliki oleh masyarakat yang berpikiran maju, dan hanya masyarakat yang berpikiran maju yang menghargai pendidikan. Pendidikan dan masyarakat merupakan satu kesatuan yang saling menentukan status. 
Sebagai institusi sosial, pendidikan merupakan bagian yang tidak terpisahkan dari sistem sosial, karena pendidikan (persekolahan) tidak dapat dilaksanakan di luar lembaga sosial. Dewey beranggapan bahwa pendidikan tumbuh di masyarakat dan masyarakat tumbuh karena adanya pendidikan. Antara kedunya terdapat hubungan yang bersifat mutual benefit, yang berarti saling menguntungkan bahkan merupakan suatu ikatan yang secara aksiomatik sulit dan mustahil untuk dipisahkan. Pendapat senada dikemukakan oleh Durkheim yang mengemukakan bahwa masyarakat secara keseluruhan masing-masing lingkungan sosial di dalamnya, merupakan sumber penentu cita-cita yang dilaksanakan lembaga pendidikan.

Hal ini menjadi pengatahuan awal di dalam memahami status dan fungsi pendidikan sebagai institusi sosial. Pemahaman itu harus terbangun dalam pikiran setiap orang dalam masyarakat. Jika hal ini tidak disadari, akan terbangun sikap acuh tak acuh terhadap dunia pendidikan. Sikap seperti itu menyebabkan sebagian masyarakat menganggap bahwa pendidikan itu bukan bagian dari urusan atau kepentingannya, tetapi hanya menjadi urusan orang-orang tertentu yang bergerak dalam dunia pendidikan.

Kesalahan memahami posisi pendidikan sebagai intitusi sosial dapat menyebabkan pendidikan kurang mendapatkan perhatian dari masyarakat. Dengan demikian, pendidikan tidak akan tumbuh secara maksimal dalam suatu masyarakat.

Tulisan ini mencoba untuk mendekati permasalahan di atas dengan pendekatan sosiologis, dengan melihat bahwa pendidikan merupakan suatu fenomena yang lahir, tumbuh, dan berkembang dalam masyarakat dan merupakan salah satu komponen terpenting dari suatu sistem sosial.

Permasalahan pokok yang akan diangkat dalam tulisan ini adalah bagaimana kedudukan pendidikan sebagai institusi sosial? Dari permasalahan pokok tersebut, maka ada dua sub masalah yang akan dibahas dalam tulisan ini, yaitu: apa yang dimaksud dengan institusi/lembaga sosial? dan mengapa pendidikan disebut sebagai institusi/lembaga sosial?

\section{PEMBAHASAN}

\section{Institusi/Lembaga Sosial}

Berbagai istilah digunakan untuk menggambarkan tentang lembaga sosial, yang merupakan terjemahan dari istilah Inggris "social institution". Kuntjaraningrat misalnya menyebutnya dengan pranata sosial, yakni suatu sistem tata kelakuan dan hubungan yang berpusat kepada aktivitas-aktivitas untuk memenuhi kompleks-kompleks kebutuhan khusus dalam kehidupan masyarakat. ${ }^{3}$ Selain pranata sosial, juga digunakan istilah bangunan sosial, dan lembaga sosial. Bangunan sosial yang dalam bahasa Jerman dikenal dengan "die soziale gebielde" yang menunjuk pada bentuk dan susunannya, atau lebih menunjuk pada bentuk luarnya. Sedangkan lembaga sosial adalah istilah yang dikemukakan oleh Selo Soemardjan dan Soelaiman Soemantri yakni semua norma dari segala tingkatan yang berkisar pada suatu keperluan pokok dalam 
kehidupan masyarakat, misalnya lembaga pendidikan, lembaga ekonomi dan sebagainya. ${ }^{4}$ Mayor Polak menggunakan istilah institusi dan assosiasi. Institusi merupakan sistem peraturan, sedangkan assosiasi ialah kelompok yang berstruktur dan bertindak menurut peraturan-peraturan tersebut. Jadi assosiasi adalah bentuk-bentuk organisasi sosial dengan tujuan-tujuan yang spesifik. ${ }^{5}$ Lembaga sosial adalah organisasi norma-norma untuk melaksanakan sesuatu yang dianggap penting. Lembaga berkembang berangsur-angsur dari kehidupan sosial manusia. Bila kegiatan itu penting tentu dibakukan, dirutinkan dan disetujui, maka perilaku itu telah melembaga. Peran yang melembaga adalah peran yang telah dibakukan, disetujui, diharapkan, dan bisanya dipenuhi dengan cara-cara yang sungguh-sungguh dapat diramalkan, terlepas dari siapa yang mengisi peran itu. ${ }^{6}$

Institusi/lembaga sosial lahir dan terdapat dalam masyarakat tanpa mengenal tingkat kebudayaannya, apakah taraf kebudayaan yang masih bersahaja atau kebudayaan moderen. Hal ini disebabkan karena setiap masyarakat mempunyai kebutuhan mendasar atau pokok yang muncul dengan sendirinya. Untuk memenuhi kebutuhankebutuhan tersebut, maka lahirlah lembaga-lembaga. Misalnya kebutuhan akan pendidikan, lahirlah lembaga pendidikan, seperti taman kanak-kanak, sekolah dasar, sekolah menengah, dan seterusnya. Kebutuhan hidup kekerabatan, melahirkan lembaga kemasyarakatan, seperti perkawinan, kebutuhan menyatakan keindahan, melahirkan kesusasteraan, seni, dan sebagainya.

Penjelasan-penjelasan tersebut menunjukkan bahwa institusi sosial merupakan sesuatu yang lahir disebabkan karena manusia memiliki kebutuhan yang harus dipenuhi oleh manusia. Untuk memenuhi kebutuhan itu, manusia tidak bisa seorang diri, melainkan memerlukan kerjasama dengan orang lain.

Jadi, dapat disimpulkan bahwa lembaga sosial atau institusi sosial merupakan kumpulan norma yang berkisar pada suatu kebutuhan pokok dalam kehidupan masyarakat. Dengan demikian, maka di dalam suatu masyarakat terdapat berbagai lembaga sosial, yang didasarkan pada jenis kebutuhan masyarakat. Semakin banyak kebutuhan masyarakat yang membutuhkan pemenuhan bersama, maka semakin banyak pula lembaga/institusi sosial yang lahir dalam masyarakat itu.

Sebelum pembahasan lebih lanjut, ada baiknya dikemukakan pula secara sepintas perbandingan beberapa istilah yang sering digunakan dan dikacaukan pengertiannya, yakni lembaga sosial, group sosial, dan organisasi sosial. Perbedaan ketiga istilah tersebut dapat dilihat pada karakteristik masing-masing sebagai berikut:

Tabel 1.

Perbedaan Lembaga Sosial, Group Sosial, dan Organisasi Sosial

\begin{tabular}{|l|l|l|l|}
\hline $\begin{array}{l}\text { Komponen yang } \\
\text { diperhatikan }\end{array}$ & Lembaga Sosial & \multicolumn{1}{|c|}{ Group Sosial } & \multicolumn{1}{|c|}{ Organisasi Sosial } \\
\hline Sifatnya & $\begin{array}{l}\text { Tidak resmi, } \\
\text { tidak ada aturan } \\
\text { tertulis, bersifat } \\
\text { abstrak }\end{array}$ & $\begin{array}{l}\text { Tidak resmi, } \\
\text { tidak ada aturan } \\
\text { tertulis, bersifat } \\
\text { abstrak }\end{array}$ & $\begin{array}{l}\text { Resmi/formal, ada } \\
\text { aturan tertulis, dan } \\
\text { bersifat konkrit }\end{array}$ \\
\hline Pola Kelakuan & Bersifat mapan & Tidak mapan & Ada durasi tertentu \\
\hline
\end{tabular}




\begin{tabular}{|c|c|c|c|}
\hline Tujuan & $\begin{array}{l}\text { Pemenuhan } \\
\text { kebutuhan } \\
\text { bersama }\end{array}$ & $\begin{array}{l}\text { Pemenuhan } \\
\text { kebutuhan } \\
\text { bersama }\end{array}$ & Ada tujuan yang jelas \\
\hline Aturan & $\begin{array}{l}\text { Ada sistem } \\
\text { norma/kontrol } \\
\text { sosial }\end{array}$ & $\begin{array}{l}\text { Tidak ada kontrol } \\
\text { sosial }\end{array}$ & $\begin{array}{l}\text { Ada aturan tertulis } \\
\text { dalam } \mathrm{AD} / \mathrm{ART}\end{array}$ \\
\hline Hubungan sosial & $\begin{array}{l}\text { Sangat kuat, } \\
\text { langsung, dan } \\
\text { bersifat pribadi }\end{array}$ & $\begin{array}{l}\text { Sangat kuat, } \\
\text { langsung, dan } \\
\text { bersifat pribadi }\end{array}$ & Bersifat inpersonal \\
\hline $\begin{array}{l}\text { Jabatan/ } \\
\text { pimpinan }\end{array}$ & $\begin{array}{l}\text { Tidak ada } \\
\text { struktur formal }\end{array}$ & $\begin{array}{l}\text { Tidak ada } \\
\text { struktur formal }\end{array}$ & $\begin{array}{l}\text { Ada struktur formal, } \\
\text { bersifat resmi, pola } \\
\text { wewenang berbentuk } \\
\text { piramida }\end{array}$ \\
\hline Jumlah anggota & Tidak terbatas & terbatas & Banyak \\
\hline $\begin{array}{l}\text { Syarat menjadi } \\
\text { pemimpin }\end{array}$ & $\begin{array}{l}\text { Biasanya } \\
\text { didasarkan pada } \\
\text { usia }\end{array}$ & Tidak ada aturan & $\begin{array}{l}\text { Berdasarkan seleksi } \\
\text { formal }\end{array}$ \\
\hline $\begin{array}{l}\text { Tempat } \\
\text { tumbuhnya }\end{array}$ & $\begin{array}{l}\text { Dalam } \\
\text { masyarakat } \\
\text { sederhana dan } \\
\text { maju/moderen } \\
\end{array}$ & $\begin{array}{l}\text { Dalam } \\
\text { masyarakat } \\
\text { sederhana dan } \\
\text { maju/moderen } \\
\end{array}$ & $\begin{array}{l}\text { Dalam masyarakat } \\
\text { moderen }\end{array}$ \\
\hline Arah kegiatan & $\begin{array}{l}\text { Tidak tertentu } \\
\text { / terbatas pada } \\
\text { bidang tertentu }\end{array}$ & $\begin{array}{l}\text { Tidak tertentu } \\
\text { / terbatas pada } \\
\text { bidang tertentu }\end{array}$ & $\begin{array}{l}\text { Mengarah pada } \\
\text { produktivitas: } \\
\text { - Menyelesaikan suatu } \\
\text { pekerjaan } \\
\text { - Memecahkan masalah } \\
\text { Mempertahankan/ } \\
\text { memperbesar out put } \\
\text { - Memperbaiki cara } \\
\text { kerja seefektif } \\
\text { mungkin. } \\
\end{array}$ \\
\hline
\end{tabular}

Lembaga sosial muncul dalam masyarakat karena adanya norma yang pada mulanya terbentuk secara tidak sengaja, lama kelamaan norma tersebut dibuat secara sadar. Mislanya, norma (ukuran) tentang pendidikan.7 Pada awalnya pendidikan bukan merupakan sesuatu yang menjadi ukuran status seseorang. Lama kelamaan pendidikan itu disadari oleh anggota masyarakat, maka pendidikan itu menjadi suatu kebutuhan yang harus dipenuhi. Pendidikan dirasakan sebagai suatu yang memberi status, maka pendidikan itu menjadi melembaga dalam masyarakat. Jadilah pendidikan sebagai salah satu intitusi sosial.

Menurut Soerjono Soekanto, suatu norma tertentu dikatakan telah melembaga (institutionalized), apabila norma tersebut:

1. Diketahui

2. Dipahami atau dimengerti

3. Ditaati, dan

4. Dihargai. ${ }^{8}$

Proses melambaganya suatu norma berawal dari norma itu mulai diketahui, walaupun masih taraf rendah. Selanjutnya norma itu dipahami sebagai sesuatu yang dapat mengatur kehidupan bersama, maka timbullah kecenderungan untuk mentaati 
norma itu. Setalah disadari bahwa norma itu memang dapat memenuhi kebutuhan masyarakat, dengan sendirinya akan tumbuh dalam masyarakat sikap menghargai dan akan berprilaku sesuai dengan norma itu.

Lembaga sosial mempunyai fungsi, yaitu:

1. Memberikan pedoman tingkah laku bagi anggota-anggotanya

2. Menjaga keutuhan masyarakat yang bersangkutan

3. Memberikan pegangan kepada masyarakat untuk mengadakan sistem pengendalian sosial (social control), yakni sistem pengawasan oleh masyarakat terhadap tingkah laku anggota-anggotanya. ${ }^{9}$

Keberadaan lembaga sosial dalam suatu masyarakat, dapat menjadikan masyarakat itu semakin tertib, utuh, dan terkendali, sebab mereka diikat oleh norma-norma yang diketahui, dipahami dan dimengerti, ditaati dan dihargai secara bersama. Semakin maju atau kompleks suatu masyarakat, semakin banyak norma-norma yang dibutuhkan yang berarti bahwa akan semakin kompleks pula lembaga yang tumbuh dalam masyarakat itu.

Lembaga sosial menjadi sesuatu yang amat penting dalam kehidupan bermasyarakat. Lembaga sosial menurut John Lewis Gillin dan John Philip Gillin dalam Gunawan, memiliki enam ciri, yaitu:

1. Lembaga sosial merupakan himpunan pola pemikiran dan tingkah laku yang dicerminkan dalam kegiatan kemasyarakatan dan hasil-hasilnya.

2. Lembaga sosial mempunyai tarap kekekalan tertentu

3. Lembaga sosial mempunyai satu atau lebih tujuan

4. Lembaga sosial mempunyai berbagai sarana untuk mencapai tujuan

5. Lembaga sosial mempunyai lambang atau simbol khas

6. Lembaga sosial mempunyai tradisi lisan maupun tertulis yang berisikan rumusan tujuan, sikap, dan tindak tanduk individu yang mengikuti lembaga tersebut. ${ }^{10}$

Kalau dicermati pendapat Gillin dan Gillin tersebut di atas, dapat dipahami bahwa sebuah lembaga sosial dapat dibedakan dari pola pemikiran dan tingkah laku dari pengikut suatu lembaga. Selain itu, setiap lembaga akan memiliki taraf dan tingkat kekekalan yang berbeda, tergantung pada anggapan orang-orang terhadap norma yang ada, apakah wajar untuk dipelihara atau tidak. Suatu lembaga sosial mempunyai satu atau lebih tujuan yang boleh jadi berbeda dengan fungsi lembaga yang bersangkutan. Tujuan suatu lembaga adalah menjadi tujuan bagi golongan masyarakat tertentu yang perlu dipegang teguh, sedang fungsi lembaga yakni peranan lembaga dalam sistem sosial mungkin tidak diketahui atau tidak disadari oleh golongan masyarakat tersebut. Setiap lembaga sosial mempunyai alat-alat perlengkapan yang digunakan untuk mencapai tujuan lembaga yang bersangkutan, serta lambang-lambang yang secara simbolis menggambarkan tujuan dan fungsi lembaga yang bersangkutan, serta masing-masing mempunyai tradisi yang berbeda, baik tertulis maupun tidak tertulis.

\section{Pendidikan sebagai Institusi Sosial}

Sebelum membahas pendidikan sebagai institusi sosial, ada baiknya dibahas terlebih dahulu lahirnya pendidikan dalam masyarakat. Seperti telah diuraikan pada 
pembahasan terdahulu, bahwa lahirnya suatu lembaga atau institusi tidak direncanakan terlebih dahulu, tetapi ia muncul untuk memenuhi kebutuhan bersama. Demikian halnya dengan pendidikan sebagai sebuah lembaga.

Dalam masyarakat yang bersahaja/primitif, mereka tidak memiliki lembaga pendidikan, apalagi yang formal. Orang tua mendidik anaknya dengan jalan memberi contoh dan anak menyaksikan secara langsung suatu pekerjaan. Cara seperti inilah yang dapat dikatakan sebagai pendidikan dalam masyarakat yang bersahaja.

Sekolah mulai lahir ketika kebudayaan telah menjadi sangat kompleks, sehingga pengetahuan yang dianggap perlu tidak mungkin lagi ditangani dalam lingkungan keluarga. Dalam perkembangan beberapa generasi selanjutnya lahirlah "gu$\mathrm{ru}^{\prime \prime}$ yaitu orang yang waktunya dipergunakan sepenuhnya untuk mengajar. Pada tahap itulah ketika telah terdapat orang-orang yang berspesialisasi guru dan anak-anak didik dalam kelas yang formal yang berlangsung di luar lingkungan keluarga, dan ketika itulah ditemukan cara yang pantas untuk mendidik anak-anak tersebut, barulah dapat dikatakan lembaga pendidikan telah lahir. ${ }^{11}$

Pendapat tersebut menggambarkan bahwa lembaga pendidikan lahir, tumbuh, dan berkembang sejalan dengan perkembangan kebudayaan yang dicapai oleh manusia. Dengan demikian, keberadaan lembaga pendidikan pada awalnya merupakan sesuatu yang tidak direncanakan atau disadari, melainkan hanya untuk memenuhi suatu kebutuhan. Dalam perkembangan selanjutnya, barulah hal itu diketahui kegunaannya, dimengerti, dipahami, ditaati, dan dihargai, karena telah menjadi sesuatu yang dianggap dapat memenuhi kebutuhan masyarakat.

Jadi, dalam analisis fungsional, pertumbuhan lembaga pendidikan dikaitkan dengan kebutuhan tenaga kerja. Artinya, bahwa lahirnya lembaga pendidikan dalam masyarakat disesuaikan dengan pertumbuhan dan perkembangan kebudayaan yang dimiliki oleh manusia. Hal ini berarti, bahwa lembaga pendidikan akan tumbuh dan berkembang seiring dengan pertumbuhan dan perkembangan kebudayaan manusia. Semakin kompleks kebudayaan yang dicapai oleh manusia, semakin kompleks pula kebutuhan manusia akan pendidikan.

Analisis aliran fungsional di atas, ditolak oleh penganut aliran konflik. Menurut aliran ini, kebutuhan akan tenaga kerja bukan merupakan faktor yang terpenting yang menjadi penyebab lahirnya lembaga pendidikan. Di negara-negara maju, banyak orang memperoleh pendidikan jauh lebih tinggi dari pada keperluan yang dibutuhkan oleh pekerjaan mereka. Penganut teori konflik, berpendapat bahwa terdapat banyak faktor yang mungkin lebih penting, lebih berpengaruh, dan merupakan penyebab lahirnya lembaga pendidikan, yaitu:

1. Untuk memenuhi kebutuhan akan status bagi orang-orang yang ingin merasa lebih hebat.

2. Ingin terbebas dari persaingan untuk memperoleh jabatan tertentu yang diperebutkan oleh orang-orang yang tidak memiliki ijazah.

3. Mempertegas jurang antar kelompok etnik dan subkultur (kebudayaan khusus) serta menganaktirikan orang-orang yang tidak diajar tata krama secara baik. ${ }^{12}$ 
Jika pandangan kedua aliran sosiologi tersebut dianalisis, dapat disimpulkan bahwa pandangan aliran fungsional memahami bahwa lembaga pendidikan itu ada sejalan dengan tingkat kebudayaan yang dicapai oleh manusia, sehingga pendidikan dianggap sesuatu yang dibutuhkan untuk memenuhi kebutuhan manusia sesuai dengan tingkat kebudayaannya. Pendidikan itu ada bersamaan dengan adanya kebutuhan manusia untuk memenuhi hajat hidupnya. Pendidikan itu tumbuh bersamaan dengan pertumbuhan kebudayaan yang dicapai oleh manusia. Semakin maju suatu masyarakat, semakin kompleks permasalahan yang dihadapi, sehingga kebutuhan terhadap pendidikan juga semakin tinggi. Teori konflik berpendapat bahwa pendidikan ada hubungannya dengan status seseorang, yang dapat membedakannya dengan orang lain, untuk menduduki suatu jabatan, dan mempertegas perbedaan antara orang terdidik dengan orang yang tidak terdidik.

Kedua pandangan ini memiliki tingkat kebenaran masing-masing jika dilihat dari pendekatan yang digunakan. Kalau aliran fungsional melihat dari pendekatan kronologis perkembangan kebudayaan manusia, dan berpendapat bahwa pendidikan berfungsi sebagai alat untuk memenuhi kebutuhan manusia. Teori konflik melihat dari sudut pandang yang berbeda. Mereka melihat bahwa lembaga pendidikan dapat mempertegas perbedaan antara orang terdidik dengan orang yang tidak terdidik, dan melihat keberadaan lembaga pendidikan dalam konteks masyarakat yang sudah maju.

Pendidikan sebagai institusi sosial yang dimaksudkan dalam uraian ini lebih diarahkan pada pendidikan formal (persekolahan). Hal ini disebabkan karena anggapan masyarakat ketika berbicara tentang pendidikan, konotasinya lebih pada pendidikan formal, walaupun dalam Undang-Undang RI No. 20 tahun 2003 tentang Sistem Pendidikan nasional dikenal tiga jalur pendidikan, yaitu jalur pendidikan formal, informal, dan nonformal.

Lembaga pendidikan dikembangkan sebagai suatu upaya sistimatis untuk mengajarkan apa yang tidak bisa dipelajari secara mudah dalam lingkungan keluarga. Lembaga pendidikan primer adalah sekolah formal, yang bermula dari taman kanakkanak hingga jenjang perguruan tinggi, baik yang dikelola oleh negara maupun yang dikelola oleh badan-badan tertentu.

Salah satu aspek pendidikan yang terdapat dalam setiap masyarakat adalah adanya asumsi yang menyangkut siapakah yang memerlukan pendidikan dan berapa banyak pendidikan yang diperlukan. Sistem pendidikan persaingan (contes education) berpandangan bahwa setiap orang harus diberi kesempatan untuk bersaing dan tidak diperlukan sponsor khusus. Sistem pendidikan sponsor (sponsored education) berpandangan bahwa setiap orang sudah masuk dalam suatu kelas sosial sejak lahir, dan jika ia memiliki kemampuan yang luar biasa dapat masuk ke kelas sosial yang lebih tinggi. ${ }^{13}$

Sekolah merupakan suatu sistem sosial yang memiliki jumlah peranan, status, dan hubungan-hubungan sendiri. Pendidikan memiliki sejumlah fungsi, yang oleh Marton, seorang fungsinalis, dikenal dengan fungsi manifest (nyata), yaitu akibat-aki- 
bat obyektif yang menyumbang pada perubahan atau adaptasi dari sistem yang disengaja dan diakui oleh para peserta dalam sistem itu. Lalu hal-hal itu bersifat terbuka, disengaja, dikenal, diakui dan diterima. Selain fungsi manifest, pendidikan juga memiliki fungsi laten yaitu fungsi yang tidak disengaja mapun diakui. Fungsi ini lebih bersifat tertutup, tidak begitu luas diakui dan diterima. ${ }^{14}$ Fungsi manifest yang utama ialah membantu orang dalam mengembangkan potensi dan mempersiapkan mereka untuk bekerja. Fungsi laten (terpendam/terselubung) mencakup, memperpanjang masa ketidakdewasaan, memperlemah pengawasan orang tua, mempertahankan atau mengubah kelas sosial, dan memberikan tempat perlindungan bagi pertikaian pendapat.

Menurut S. Nasution, sekolah mempunyai beberapa fungsi, yaitu:

1. Mempersiapkan anak untuk suatu pekerjaan

2. Memberikan keterampilan dasar

3. Membuka kesempatan untuk memperbaiki nasib.

4. Menyediakan tenaga pembangunan

5. Membantu memecahkan masalah-masalah sosial.

6. Mentransmisi kebudayaan.

7. Membentuk manusia yang sosial.

8. Merupakan alat mentransformasikan kebudayaan.

9. Sebagai tempat menitipkan anak. ${ }^{15}$

Jika dilihat dari pemaknaan institusi sosial sebagai norma untuk memenuhi kebutuhan pokok dalam hidup manusia, dan dilihat dari fungsi pendidikan (sekolah) yang dikemukakan oleh Nasution sebelumnya, pendidikan dapat dikategorikan sebagai salah satu institusi sosial, selain keluarga, agama, politik, dan ekonomi.

Apabila dilihat dari perkembangan lembaga sosial, pendidikan dapat dikategorikan sebagai lembaga enacted (ditumbuhkan dengan sengaja), yang menurut Sumner dalam Ary Gunawan, tipe ini berakar pada kebiasaan-kebiasaan dalam masyarakat, lalu disistimatisasikan dan diatur, kemudian dituangkan menjadi lembaga positif (yang berlaku), dikukuhkan oleh hukum, disahkan oleh pemerintah/negara. Jika dilihat dari kepentingannya, lembaga pendidikan ini termasuk santioned institution (diterima), yaitu lembaga yang diterima oleh masyarakat. Kalau dilihat dari penyebarannya, maka lembaga pendidikan ini termasuk dalam general institution (menyeluruh), yakni lembaga sosial yang terdapat hampir di seluruh masyarakat, seperti halnya dengan politik, keamanan dan sebagainya. ${ }^{16}$

Lembaga pendidikan merupakan salah satu sumber kontrol sosial, yang bertujuan untuk mengadakan perubahan. Pendidikan merupakan tempat untuk memikirkan, menganalisis, apa yang sedang terjadi dalam masyarakat. Lembaga pendidikan harus bersikap independen (tidak terikat) oleh unsur-unsur lain dalam mengadakan analisis terhadap situasi yang terjadi dalam masyarakat, walaupun disadari akan berhadapan dengan pihak yang berusaha untuk mempertahankan status quo.

Sekolah merupakan "agent of change", lembaga pengubah. Sekolah mempunyai fungsi transformatif, setidaknya sekolah harus mampu mengikuti laju perkembangan 
agar masyarakat tidak ketinggalan dalam kemampuan dan pengetahuan dibanding bangsa lain. Dalam dunia yang dinamis, setiap masyarakat akan mengalami perubahan. Jika tidak, maka akan membahayakan bagi eksistensi masyarakat, sehingga sekolah harus menyesuaikan diri dengan perubahan yang terjadi. Perubahan itu mengharuskan sekolah mengadakan perubahan berupa pembaruan kurikulum dan sistem pendidikan. ${ }^{17}$

Peran lembaga pendidikan memang sangat penting dan strategis, mengingat bahwa pendidikan merupakan salah satu lembaga yang dapat dijadikan sebagai pelopor pembaruan dalam masyarakat.

Kebijakan pendidikan harus memperhitungkan berbagai perubahan masyarakat yang terjadi dalam berbagai bidang kehidupan, agar semakin realistis dan sesuai dengan tantangan pada zaman yang selalu berubah. Ini berarti bahwa strategi pembangunan pendidikan ditekankan pada investasi sumber daya manusia. Pendidikan dapat menjadi katalisator utama dalam pembangunan SDM. ${ }^{18}$

Berdasarkan uraian di atas, dapat disimpulkan bahwa pendidikan merupakan institusi sosial, karena pendidikan dapat memenuhi kebutuhan mendasar masyarakat berupa pengetahuan. Pendidikan akan selalu hadir dalam masyarakat pada semua tingkat kebudayaan, mulai dari yang paling bersahaja sampai pada kebudayaan modern. Pendidikan akan selalu menjawab tantangan zaman yang selalu berubah, menjaga eksistensi suatu masyarakat, dan berbagai fungsi pendidikan seperti telah dikemukakan di atas. Akan tetapi, pendidikan tidak identik dengan persekolahan saja, karena pendidikan dapat berlangsung dalam jalur informal, formal, dan nonformal, sedangkan persekolahan lebih identik dengan pendidikan jalur formal.

\section{SIMPULAN}

Berdasarkan uraian yang telah dikemukakan, dapat ditarik kesimpulan sebagai berikut:

Bahwa lembaga sosial atau institusi sosial merupakan kumpulan norma yang berkisar pada suatu kebutuhan pokok dalam kehidupan masyarakat. Lembaga/institusi sosial akan lahir untuk menjawab setiap kebutuhan mendasar dari suatu masyarakat. Jika disederhanakan, lembaga sosial yang tumbuh dalam masyarakat, meliputi lembaga keluarga, agama, pendidikan, ekonnomi, dan politik.

Pendidikan sebagai institusi sosial, karena pendidikan itu lahir dalam masyarakat dengan tidak mengenal tingkat kebudayaan untuk menjawab dan memenuhi hajat hidup suatu masyarakat. Hal ini terlihat dalam fungsi-fungsi yang diemban oleh lembaga pendidikan (sekolah). Selain itu pendidikan dikatakan telah melembaga karena ia diketahui, dipahami/dimengerti, ditaati, dan dihargai.

\section{CATATAN AKHIR}

1. Paul B. Horton dan Chester L. Hunt, Sociology, terj. Aminuddin Ram, Sosiologi, Jil. 1, Cet. IV; Jakarta: Erlangga, 1996, h. 339.

2. Muhyi Batubara, Sosiologi Pendidikan, Cet. I; Jakarta: Ciputat Press, 2004, h. 78. 
3. Kuntjaraningrat, Pengantar Antropologi, Cet. II; Jakarta: Penerbit Universitas, 1964, h. 113.

4. Ary H. Gunawan, Sosiologi Pendidikan Suatu Analisis Sosiologi Tentang Pelbagai Problem Pendidikan, Cet. I; Jakarta: Rineka Cipta, 2000, h. 23.

5. Ibid.

6. Apip Sohibul Fajori, Budaya dan Institusi Sosial, diakses dari internet http://faroji83. wordpress.com/2008/06/10/etnometodology/, pada tanggal 2 Peberuari 2011,

7. WJS. Poerwadarminta, Kamus Umum Bahasa Indonesia, Cet. V; Jakarta: PN. Balai Pustaka, 1976, h. 678.

8. Soerjono Soekanto, Sosiologi Suatu Pengantar, Cet. XXVII; Jakarta: PT. Raja Grafindo Persada, 1999, h. 224.

9. Ary H. Gunawan, op. cit., h. 28.

10. Ibid., h. 29. Lihat pula dalam Soerjono Soekanto, op. cit., h. 230-232

11. Paul B. Horton dan Chester L. Hunt, op. cit., h. 333.

12. Ibid., h. 334

13. Apip Sohibul Fajori, Budaya dan Institusi Sosial, http://faroji83. wordpress.com/2008/06/10/etnometodology/, diakses pada tanggal 2 Peberuari 2011.

14. Frank Jefflen, Sydney C. Mifflen, Sosiology of Education diterjemahkan oleh Joost Kullit dengan judul "Sosiologi Pendidikan", Bandung: Tarsito, 1986, h. 437.

15. S. Nasution, Sosiologi Pendidikan, Cet. III; Jakarta: Bumi Aksara, 2004, h. 14-17.

16. Ary H. Gunawan, op. cit., h. 29-30.

17. Nasution, op. cit., h. 22-23.

18. Muhyi Batubara, Sosiologi Pendidikan, Cet. I; Jakarta: Ciputat Press, 2004, h. 6.

\section{DAFTAR PUSTAKA}

Ahmadi, Abu. Sosiologi Pendidikan. Cet. II; Jakarta: Rineka Cipta, 2004.

Batubara, Muhyi, Sosiologi Pendidikan. Cet. I; Jakarta: Ciputat Press, 2004.

Horton, Paul B. dan Chester L. Hunt. Sociology. Terj. Aminuddin Ram. Sosiologi. Jil. 1, Cet. IV; Jakarta: Erlangga, 1996.

Jefflen, Frank dan Sydney C. Mifflen. Sosiology of Education. Terj. Joost Kullit. Sosiologi Pendidikan. Bandung: Tarsito, 1986.

Johnson, Doyle Paul. Sosiological theory Classical Founders and Contemporary Perspectives. Terj. Robert M.Z. Lawang. Teori Sosiologi Klassik dan Moderen. Jil. 2, Jakarta: Gramedia, 1986.

Nasution, S. Sosiologi Pendidikan. Cet. III; Jakarta: Bumi Aksara, 2004.

Poerwadarminta, WJS. Kamus Umum Bahasa Indonesia. Cet. V; Jakarta: PN. Balai Pustaka, 1976.

Roucek, J.S, R.L. Werren. Sociology and Introduction. Terj. Sahat Simamora. Pengantar Sosiologi. Jakarta: Bina Aksara, 1984.

Soekanto, Soerjono. Sosiologi Suatu Pengantar. Cet. CXXVII; Jakarta: PT. Raja Grafindo Persada, 1999.

Sohibul Fajori, Apip. Budaya dan Institusi Sosial. website, diakses pada tanggal 2 Peberuari 2011. 